V. 13 N. 2

MAIO-AGO 2017

ISSN 2317-6172

Recebido: 09.01.2015

Aprovado: 06.02.2017

DOI: http://dx.doi.org/10.1590/2317-6172201717

1 Universidade Estadual Paulista (UNESP) Franca - SP - Brasil

\section{Sobre a proteção contra a conduta desleal dos Estados no comércio internacional: as ambiguidades de sua disciplina jurídica e de seus fundamentos no direito da OMC}

ON UNFAIR STATE ACTS IN INTERNATIONAL TRADE IN ACCORDANCE TO THE WTO LAW: THE AMBIVALENCE OF ITS DISCIPLINE AND ITS JUSTIFICATIONS

Daniel Damásio Borges ${ }^{1}$

\section{Resumo}

A competição pelo mercado internacional mobiliza não apenas empresas, mas igualmente Estados. Com efeito, políticas públicas são adotadas com vistas a aumentar a participação de empresas domésticas no mercado internacional. Por esses motivos, surge o seguinte questionamento: determinadas condutas estatais podem ser consideradas desleais pelas normas do sistema multilateral do comércio, ao desequilibrarem o jogo da concorrência internacional em favor das empresas nacionais? 0 direito da OMC responde afirmativamente a essa questão, ao autorizar os seus membros a reagirem ao dumping e aos subsídios por meio de instrumentos de defesa comercial. Tal autorização fundamenta-se na finalidade de assegurar uma certa isonomia entre os atores do comércio internacional. Isso, porém, não significa dizer que as medidas antidumping e contra os subsídios sejam sempre benéficas e isentas de custos econômicos. Convém, assim, aprofundar o debate sobre o uso desses instrumentos de defesa comercial.

\section{Palavras-chave}

Comércio internacional; concorrência desleal; direito da OMC; dumping; subsídios.

\section{Abstract}

The competition for world market shares involves not only companies, but also States. In fact, public policies are adopted in order to aid domestic enterprises to increase their share in the world market. For this reason, it is often questioned whether some State acts can be considered unfair acts, since they prevent a competition on a "level playing field". The WTO law responds this question affirmatively, because it allows its members to react against dumping and subsidies. This authorization aims to protect domestic companies from unfair competition. However, this authorization does not mean that antidumping and countervailing measures are always good trade policies and free from economic costs. Therefore, the use of these trade policies instruments should be submitted to additional debate.

\section{Keywords}

World trade; unfair trade practices; WTO law; dumping; subsidies. 


\section{INTRODUÇÃO}

Em discurso proferido na abertura da $67^{a}$ Assembleia Geral das Nações Unidas, a então presidente Dilma Rousseff procurou justificar as medidas de proteção à indústria nacional adotadas por seu governo. Segundo a presidente, não se deve confundir protecionismo com iniciativas legítimas de defesa comercial, autorizadas pelas normas da Organização Mundial do Comércio (OMC). Para a presidente, não apenas o protecionismo, mas também todas as formas de manipulação do comércio devem ser combatidos, já que atribuem mais competitividade de maneira espúria e fraudulenta. ${ }^{1}$

Essa distinção feita pela presidente inseriu-se no contexto de suas críticas às políticas monetárias dos países desenvolvidos, adotadas após a eclosão da crise econômica internacional de 2008. Para ela, tais políticas monetárias expansionistas causam uma desvalorização artificial das moedas desses países, o que acarreta a perda de participação dos países desenvolvidos no mercado internacional. Desse modo, pode-se concluir que, na visão da presidente, as medidas comerciais restritivas brasileiras são uma reação plenamente justificada a uma conduta desleal - praticada pelos concorrentes do Brasil no comércio internacional.

Em matéria de política comercial, outras declarações de chefes de Estado e de governo já foram feitas em sentido semelhante. Em uma conhecida mensagem lida no rádio, o presidente norte-americano Ronald Reagan (1981-1989) afirmou que a defesa do livre-comércio (free trade) deveria ser realizada em conjunto com a do comércio leal (fair trade). ${ }^{2}$ Para Reagan, determinados Estados não agem no comércio internacional seguindo os parâmetros da concorrência leal, subsidiam suas indústrias e lhes conferem vantagens indevidas. Por esses motivos, prosseguiu Reagan, os Estados Unidos impõem medidas para que

1 Discurso da Presidente da República, Dilma Rousseff, na abertura da $67^{a}$ Assembleia Geral das Nações Unidas, em 25 de setembro de 2012. Disponível em: http: / / www2.planalto.gov.br/acompanhe-o-planalto/discursos/discursos-da-presidenta/discurso-da-presidenta-da-republica-dilma-rousseff-na-abert ura-da-67a-assembleia-geral-das-nacoes-unidas-nova-iorque-eua. Acesso em: 31 out. 2014.

2 Em seu discurso, Reagan relacionou o fair trade ao fair play, isto é, a um jogo em que a competição ocorre seguindo determinados parâmetros de lealdade entre os jogadores. Por esse motivo, a expressão comércio leal nos parece ser a mais adequada, nesse contexto, para traduzir a expressão em língua inglesa fair trade. Além disso, no direito norte-americano, a concorrência desleal é denominada unfair competition. Sobre a disciplina da concorrência desleal no direito norte-americano, ver: Norton (1999, p. 225-255). Conforme afirma Jacob Viner, a expressão fair trade já era utilizada no final do século XIX: "This minority report was sympathetic with those who advocated the substitution for England's free-trade policy of a policy of 'fair trade'. By 'fair trade' they meant placing home and foreign producers at an equal level with regard to artificial conditions of production caused by such things as export bounties, dumping under protection of high tariffs in the domestic market, and indirect taxation, but not interfering with natural differences in conditions of production. They distinguished the fair trade from the protectionist policy inasmuch as it was the aim of the latter, but not of the former, to offset natural differences in conditions of production" (VINER, 1991, p. 49-50). 
os demais Estados ajam seguindo os preceitos da concorrência leal. Segundo o presidente norte-americano, deveria haver um nivelamento do campo em que sucede a concorrência internacional. ${ }^{3}$

Essas manifestações públicas sugerem uma diferenciação clara entre as medidas comerciais restritivas, puramente protecionistas, e as medidas também restritivas, mas que são uma resposta justificada a condutas comerciais desleais por parte de parceiros comerciais. Diante desse quadro, é pertinente a seguinte pergunta: as normas do sistema multilateral do comércio referendam esse tipo de distinção? Caso a resposta a essa primeira questão seja afirmativa, deve-se, também, indagar: quais são os fundamentos éticos e econômicos dessa diferenciação?

Em uma primeira aproximação a esse problema, convém lembrar que a proteção da lealdade na concorrência é um capítulo clássico do direito comercial comparado. Em diferentes ordenamentos jurídicos nacionais, a exemplo do brasileiro, ${ }^{4}$ sancionam-se condutas dos comerciantes que se utilizam de práticas fraudulentas para angariar a clientela de seus concorrentes. A Convenção de Paris para a Proteção da Propriedade Industrial estabelece, em seu art. $10^{\circ}$ bis, a obrigação aos Estados partes de instituírem uma proteção efetiva em benefício dos nacionais de tais Estados contra condutas desleais de seus concorrentes. O artigo traz uma definição de concorrência desleal como sendo qualquer ato de concorrência contrário aos usos honestos em matéria industrial ou comercial. A disposição contém um rol exemplificativo de formas de concorrência desleal: a) todos os atos suscetíveis de, por qualquer meio, estabelecer confusão com o estabelecimento, os produtos ou a atividade industrial ou comercial de um concorrente; b) as falsas afirmações no exercício do comércio, suscetíveis de desacreditar o estabelecimento, os produtos ou a atividade industrial ou comercial de um concorrente; e c) as indicações ou afirmações, cuja utilização no exercício do comércio seja suscetível de induzir o público em erro sobre a natureza, modo de fabricação, características, possibilidades de utilização ou quantidade das mercadorias.

De igual modo, o Acordo sobre Aspectos dos Direitos de Propriedade Intelectual Relacionados ao Comércio da OMC contém diferentes disposições que obrigam os membros dessa organização internacional a combater práticas comerciais desleais perpetradas por agentes privados que buscam aumentar as suas vendas no mercado. ${ }^{\mathbf{5}}$

3 Radio Address on the Nation on Free and Fair Trade. Discurso do Presidente Ronald Reagan de 2 de agosto de 1986 (Disponível em: <http://www.presidency.ucsb.edu/ws/?pid=37698>. Acesso em: 4 nov. 2014 ). Foi durante a administração Reagan que o tema do fair trade tornou-se prioritário na agenda da política comercial norte-americana. Sobre o assunto, ver: Bhagwati (1997, p. 9-40).

$4 \quad$ Ver, por exemplo, Pirovano (1974, p. 467-504); Mermillod (1954) e Tinoco Soares (1989, p. 249-272).

5 Vejam-se, por exemplo, os artigos 22 e 38 do referido acordo. 
Dessa forma, o direito comparado e o direito internacional consagraram a noção de que a liberdade de comércio não é ilimitada. Os agentes privados que disputam entre si a mesma clientela devem pautar as suas estratégias comerciais por certos princípios e não podem falsear as regras do jogo da livre concorrência.

A proteção da lealdade na concorrência tem, assim, encontrado guarida no direito privado de diferentes Estados, sendo inclusive disciplinada por convenções internacionais, como a mencionada Convenção de Paris. O foco dessa disciplina, conforme salientado, são as condutas dos agentes privados em seu esforço para atrair a clientela dos concorrentes e as sanções a serem impostas pelos Estados caso essas condutas fujam dos parâmetros da concorrência leal.

Os discursos dos chefes de Estado e de governo, acima mencionados, situam-se, contudo, em outro registro: a ênfase recai sobre as condutas dos Estados que falseiam a concorrência internacional, e não dos agentes privados. Nesse caso, o centro da análise não é o direito privado, mas o direito internacional público. Mais precisamente, as normas do direito da OMC que regem as condutas dos Estados na seara comercial.

Decerto, em razão da privatização de empresas estatais, os Estados atuam cada vez menos na condição de operadores diretos do comércio internacional - na qualidade de compradores ou de vendedores de bens e de serviços. As trocas econômicas são hoje realizadas, em grande medida, por operadores privados: indivíduos e pessoas jurídicas de direito privado. ${ }^{6}$ Portanto, são os agentes privados, ao menos na maioria dos casos, que disputam entre si diretamente o mercado.

Mas a concorrência internacional tem, também, uma outra dimensão, que se situa no plano das relações entre os Estados. À sombra da rivalidade comercial entre empresas privadas, há um conjunto de ações estatais que visam a favorecer as empresas nacionais nesse domínio. Existe, por exemplo, subjacente à disputa entre Bombardier e Embraer pelo mercado internacional de aeronaves regionais, um diferendo entre Canadá e Brasil sobre as ações de cada qual em benefício de suas empresas domésticas. ${ }^{7}$

É, aliás, natural que os Estados busquem apoiar as suas empresas na disputa por uma maior participação no mercado internacional. Empresas que alcançam significativas participações

6 Não se pode, contudo, negligenciar a importância das compras governamentais para o comércio internacional. A Organização para a Cooperação e Desenvolvimento Econômico (OCDE) estima que o montante das compras governamentais em todos os níveis da administração, sem contar as despesas com material militar, cheguem a $7,1 \%$ do PIB mundial ou a $30 \%$ das exportações mundiais. Sobre o assunto, ver Crontiras e Ruiz (2003, p. 37).

7 Os exemplos desse fenômeno são inúmeros. Apenas para nos restringir ao mercado da aviação internacional, pode-se mencionar o diferendo entre Estados Unidos e União Europeia sobre os subsídios concedidos, respectivamente, à Boeing e à Airbus com o objetivo de reforçar a posição concorrencial dessas duas empresas em tal mercado. Sobre o litígio entre Brasil e Canadá, ver: Sullivan (2003, p. 245-300). 
em tal mercado são importantes fontes de divisas para a economia nacional, de empregos e de receitas fiscais. É notável, assim, o enlace entre os interesses privados de empresas e o interesse público. Daí a implementação de políticas públicas que tenham por finalidade tal apoio.

Deveras, políticas públicas exercem uma influência importante sobre a competitividade das empresas nacionais. As ações dos Estados em matéria cambial, tributária, educacional e de infraestrutura em transportes e comunicações podem conferir a essas empresas uma vantagem decisiva na disputa pelo mercado internacional. ${ }^{8}$ Por esses motivos, os poderes públicos adotam estratégias para que a participação das empresas nacionais no comércio internacional cresça cada vez mais.

Diante desse quadro, é perfeitamente pertinente a indagação sobre a natureza leal ou desleal das estratégias e ações dos Estados no comércio internacional. O objetivo desse artigo é justamente contribuir para esse debate, como base no direito vigente da OMC.

Em verdade, o direito da OMC não traz uma definição da lealdade da concorrência sob o ponto de vista das condutas dos Estados. Todavia, há normas da OMC que autorizam os membros dessa organização a reagirem, por instrumentos de defesa comercial, contra determinadas práticas comerciais. São justamente as normas da OMC sobre os subsídios e o dumping que disciplinam, de modo detalhado, essa temática. Por essa razão, ao analisar essas normas, pode-se averiguar se o direito da OMC acolheu a noção de lealdade no comércio internacional na perspectiva das condutas estatais e sob quais fundamentos.

Para levar ao cabo essa investigação, é preciso, em primeiro lugar, estudar as práticas comerciais que podem ser caracterizadas como subsídios e dumping e as medidas comerciais que os membros ${ }^{9}$ da OMC podem empregar para lhes fazer face (Parte 1). A partir dessa

8 O empresariado brasileiro critica, de modo recorrente, as deficiências das políticas públicas brasileiras que prejudicam a competitividade dos bens e serviços por ele produzidos. É muito comum entidades do agronegócio afirmarem que esse setor econômico seria muito eficiente "para dentro da porteira das fazendas", ao passo que existiram muitos problemas "para fora da porteira", sobretudo a infraestrutura de transportes muito falha. Do mesmo modo, industriais afirmam que são competitivos "para dentro das fábricas", enquanto que deficiências "para fora das fábricas", a exemplo da infraestrutura, do sistema tributário e do câmbio, prejudicam ou chegam mesmo a anular esses ganhos de produtividade. Ainda que essas afirmações possam minimizar os problemas internos de eficiência de empresas industriais e do agronegócio, é indiscutível que políticas públicas exercem uma influência muito importante sobre tal competitividade. Para um exemplo dessas reclamações do empresariado nacional, ver: "Só tenho medo de crise se houver desemprego no país, diz Tramontina". Jornal Folha de São Paulo, 11 de outubro de 2014. Disponível em: http://www1.folha.uol.com.br/mercado/2014/10/1531016-sotenho-medo-de-crise-se-houver-desemprego-no-pais-diz-tramontina.shtml. Acesso em: 5 nov. 2014.

9 Nos termos do artigo XII do Acordo de Marraqueche, qualquer Estado ou território aduaneiro distinto que possua plena autonomia na condução das suas relações comerciais externas e em relação a outras questões previstas nos Acordos da OMC pode ser membro dessa organização internacional. 
análise, é possível identificar as razões que justificam, no direito da OMC, a repressão ao subsídio e ao dumping e a sua pertinência ao tema da lealdade das condutas dos Estados no comércio internacional (Parte 2).

\section{As NORMAS DA OMC SOBRE SUBSÍDIOS E DUMPING: A DISCIPLINA DESSAS}

CONDUTAS COMERCIAIS E DAS RESPOSTAS QUE OS MEMBROS PODEM ADOTAR PARA LHES FAZER FACE

As normas da OMC estabelecem o que pode ser caracterizado como um subsídio (1.1) e o que pode ser considerado um dumping (1.2). A partir dessas definições, o direito da OMC autoriza os seus membros a reagirem a essas práticas comerciais, por meio de medidas de proteção comercial.

\section{I AS NORMAS DA OMC SOBRE OS SUBSÍdIOS: UMA FORMA ESPECÍFICA DE AÇÃO ESTATAL} EM FAVOR DAS EMPRESAS DOMÉSTICAS

As normas da OMC sobre os subsídios podem ser reagrupadas em dois subconjuntos. De início, serão abordados os conceitos chaves previstos no Acordo sobre subsídios e medidas compensatórias (Acordo SMC) que condicionam as obrigações que são nele estabelecidas (1.1.1). A partir desses conceitos, o Acordo SMC define os instrumentos jurídicos de que os membros da OMC dispõem para remediar as violações dessas obrigações (1.1.2).

\section{I.I. I A tipologia dos Subsídios fundada EM SEUS EFEITOS COMERCiais}

O primeiro artigo do Acordo SMC traz a definição de subsídio. Nos termos do referido artigo, dois elementos distintos devem estar presentes para que "o subsídio" seja caracterizado: uma contribuição financeira do membro da OMC e a vantagem correspondente a essa contribuição.

Em relação à contribuição financeira do membro da OMC, o artigo traz exemplos do que podem ser enquadrados nessa noção, como a transferência direta de fundos públicos, a renúncia de receitas públicas e o fornecimento de bens e de serviços que não sejam destinados à infraestrutura geral. É notável essa última ressalva do artigo $1^{\circ}$ do Acordo SMC: as ações do Poder Público que dizem respeito à criação ou às melhorias da infraestrutura geral não são uma contribuição financeira e não podem, portando, serem qualificadas como subsídios. Esse exemplo é tanto mais importante quanto é sobejamente conhecido que as obras públicas em transportes e telecomunicações destinadas ao público em geral melhoram consideravelmente a competitividade das empresas nacionais. ${ }^{10}$ Desse modo, nem todas 
as ações do Poder Público que melhoram essa competitividade são subsídios, tal como o direito da OMC os define.

No tocante ao segundo elemento da definição de subsídio - a vantagem conferida pela contribuição financeira do membro da OMC -, o Órgão de Apelação do sistema de solução de controvérsias da OMC adotou o mercado como critério para a sua identificação. Para o Órgão de Apelação, o termo vantagem comporta uma forma de comparação: ela existe se o seu beneficiário se encontra em uma posição melhor que na ausência de contribuição financeira. Para averiguar tal posição, prosseguiu o Órgão de Apelação, deve-se verificar se a contribuição financeira foi concedida em condições melhores que aquelas disponíveis no mercado (ÓRGÃO DE APELAÇÃO DA OMC, 1999a, § 157). ${ }^{11}$

Com fulcro nessa definição prevista no artigo $1^{\circ}$, o Acordo SMC estabelece uma distinção entre subsídios proibidos e subsídios que podem ser objeto de uma ação. ${ }^{12}$ Nos termos do artigo $3^{\circ}$ do referido acordo, subsídios proibidos são aqueles condicionados à exportação ou ainda aqueles que são condicionados ao uso de bens nacionais em detrimento dos bens importados. Consoante esse artigo, os membros da OMC não poderão conceder ou manter esse tipo de subsídio. Daí a sua designação de subsídios proibidos.

A característica marcante do subsídio proibido é o seu grande efeito sobre o comércio internacional. No caso dos subsídios subordinados às exportações, eles conduzem o beneficiário a preferir a exportação às vendas no mercado interno. Na hipótese dos subsídios condicionados ao uso de bens nacionais, eles levam os beneficiários a escolherem estes bens em prejuízo dos bens importados. Por essas razões, tais subsídios têm um impacto

uma melhora significativa da infraestrutura de transportes na América Latina teria uma repercussão maior em termos de aumento de exportações que acordos de liberalização comercial. Ver Blyde, Moreira e Volpe (2008).

11 No mesmo sentido, o Órgão de Apelação afirmou em um outro litígio: "A market benchmark can tell us whether a benefit exists and usually its size. However, in the absence of a market benchmark, it will not be possible to establish if a subsidy exists at all. That a financial contribution confers an advantage on its recipient cannot be determined in absolute terms, but requires a comparison with a benchmark, which, in the case of subsidies, derives from the market. This is so, in our view, regardless of whether the advantage needs to be precisely quantified or not" (ÓRGÃO DE APELAÇÃO DA OMC, 2013, §5.164).

12 A Parte IV do Acordo SMC é dedicada a um terceiro tipo de subsídio: subsídios que não dão lugar a uma ação. Tal seção desse acordo estabelece que os subsídios às atividades de pesquisa, às regiões desfavorecidas e à adaptação de estabelecimentos às prescrições ambientais não podem fazer parte de uma ação, desde que essas subvenções respeitem as condições enunciadas no Acordo SMC. No entanto, nos termos do artigo 31 do Acordo SMC, essas disposições serão aplicadas apenas durante o período de cinco anos, contados da data em vigor dos acordos da OMC, sob reserva de prorrogação. Visto que tal prorrogação não foi feita, a Parte VI do Acordo SMC tornou-se caduca. Por esse motivo, não abordaremos esse terceiro tipo de subsídio neste artigo. 
substancial sobre outros membros da OMC que produzem bens concorrentes aos produtos subsidiados.

Quanto aos subsídios que podem dar lugar a uma ação, eles estão submetidos a uma disciplina distinta. A primeira característica desse tipo de subsídio é a da especificidade, isto é, a de ser próprio a uma empresa ou a um ramo de atividade ou grupo de empresas. Por esse motivo, subsídios que beneficiam o conjunto da economia nacional não fazem parte dessa categoria.

A especificidade, enunciada no artigo $2^{\circ}$ do Acordo SMC, não é suficiente para configurar um subsídio que pode dar lugar a uma ação. A parte III do Acordo SMC descreve, em detalhes, todos os elementos que o compõem. Em especial, o artigo $5^{\circ}$ preceitua a obrigação aos membros da OMC de não causarem efeitos desfavoráveis sobre os interesses comerciais de outros membros ao recorrerem aos subsídios.

Nessa categoria de subsídio, ao contrário do que sucede com os subsídios proibidos, não é necessário que a outorga da contribuição financeira do membro da OMC seja condicionada à exportação ou à compra de bens nacionais. A questão do comércio exterior, nesse caso, refere-se a uma outra dimensão: os efeitos do subsídio sobre as exportações e importações dos demais membros da OMC. É por esse motivo que, nos contenciosos comerciais sobre esses subsídios, as análises econômicas relacionadas às repercussões comerciais do subsídio ocupam um lugar de primeiro plano. No litígio sobre os subsídios norte-americanos ao algodão, por exemplo, diversos estudos econômicos foram mencionados para demonstrar que esses subsídios impediam uma alta dos preços do algodão no mercado internacional, haja vista a grande participação norte-americana na produção mundial desse bem agrícola. Tal efeito econômico prejudicava as exportações brasileiras, visto que ele diminuía os preços do algodão exportado pelo Brasil (ÓRGÃO DE APELAÇÃO DA OMC, 2005, § 408). ${ }^{13}$

Convém, aqui, enfatizar: segundo o regime jurídico dos subsídios que podem dar lugar a uma ação, a concessão de subsídios, em si, não é proibida. O objeto da proibição é outro: o ato de causar efeitos desfavoráveis sobre os outros membros da OMC por meio da concessão de subsídios. Nos termos do artigo $7^{\circ}, \S 8^{\circ}$ do Acordo SMC, quando um relatório do Painel ou do Órgão de Apelação adotado pelo Órgão de Solução de Controvérsias da OMC (OSC) determinar a existência desse tipo de subsídio, o membro da OMC deve retirar o subsídio ou adotar as medidas apropriadas para eliminar os seus efeitos desfavoráveis. Por conseguinte, como bem observa Hubert Lesaffre (2007), a ilicitude do subsídio confunde-se com o seu efeito, visto que esse último constitui um dos elementos que configuram a própria violação da obrigação. 2004, § 7.1156-7.1416). 
Alicerçado na distinção entre os subsídios acima referidos, o Acordo SMC define os dois instrumentos jurídicos de que dispõem os membros da OMC lesados por essa prática comercial para lhe fazer face.

\section{I. 2 OS REMÉDIOS JURÍDICOS CONTRA OS SUBSÍDIOS}

O primeiro consiste em ingressar com uma reclamação no mecanismo de solução de controvérsias da OMC contra o membro que pratica subsídios. A esse respeito, há um rigor muito maior em relação aos subsídios proibidos em relação aos subsídios que podem dar lugar a uma ação, a exemplo de prazos mais estreitos para a solução da controvérsia. Esse maior rigor explica-se facilmente: o comércio internacional é parte integrante do próprio modus operandi dos subsídios proibidos, o que aumenta consideravelmente as possibilidades de danos à produção e à exportação de outros membros da OMC.

Quanto ao segundo meio de defesa dos membros da OMC contra os subsídios, o Acordo SMC autoriza-os a impor medidas compensatórias sobre os bens subsidiados. O exercício desse direito é, todavia, submetido a diversas condições. Antes de impor tais medidas, o membro importador deve proceder a uma investigação na qual fiquem demonstrados o subsídio ao bem importado, o dano à produção nacional e o nexo de causalidade entre ambos.

A medida compensatória que pode ser imposta ao bem subsidiado consiste em um direito especial que incide sobre ele e que não pode ultrapassar o quantum do subsídio. Tal medida, ainda segundo o Acordo SMC, apenas permanecerá em vigor pelo tempo e na medida necessários para neutralizar o subsídio. A aplicação do direito compensatório tem, assim, uma finalidade clara: tornar sem efeito a vantagem comercial de que o bem importado usufrui por conta do subsídio.

Esses direitos dos membros da OMC lesados pelos subsídios têm uma contrapartida substancial: eles não podem fazer uso de nenhuma outra medida para reagir a essa conduta comercial. ${ }^{14} \mathrm{O}$ litígio sobre a Emenda Byrd serve de ilustração sobre a importância dessa contrapartida. Na espécie, tratava-se de julgar a conformidade com o direito da OMC da disposição da lei interna norte-americana - de autoria do senador democrata Robert Byrd - que atribuía aos produtores nacionais norte-americanos afetados por subsídios o direito de receberem a quantia arrecadada pela cobrança das medidas compensatórias. Essa disposição da lei norte-americana foi condenada pelo OSC, justamente por não constituir uma das formas admitidas pelo direito da OMC de reação aos subsídios (ÓRGÃO DE APELAÇÃO DA OMC, 2005, § 408).

Portanto, o objeto das regras da OMC não é apenas de restringir o recurso aos subsídios

Veja-se, especialmente, o art. 32 do Acordo SMC. 
no comércio internacional, mas também o de limitar as medidas tomadas a título de reação a eles. A mesma ordem de considerações permeia as regras da OMC sobre o dumping, conforme se verá a seguir.

\section{I.2 AS NORMAS DA OMC SOBRE O DUMPING: A EXPORTAÇÃO DE BENS ABAIXO DE SEU} PREÇO NORMAL

Contrariamente ao que sucede com o subsídio, o dumping não é definido pelas normas da OMC como uma conduta estatal. Trata-se, na verdade, da conduta de empresas no comércio internacional - as quais são, em geral, pessoas jurídicas de direito privado. ${ }^{15}$ Nos termos do artigo VI, $\S 1$ do Acordo Geral de Tarifas e Comércio de 1994 (General Agreement on Tariffs and Trade - GATT 1994), o dumping é definido como a introdução de bens provenientes de um membro da OMC no mercado de um outro a preço inferior ao seu valor normal (WORLD TRADE ORGANIZATION, 1994).

Como se percebe, o centro de gravidade do regime jurídico do dumping é a noção de valor normal - o parâmetro a partir do qual se verifica se o bem está sendo vendido a um preço que caracteriza essa conduta comercial desleal.

Diferentes métodos são admitidos pelo direito da OMC para aferir o valor normal de um bem. O primeiro deles é o preço praticado no curso de operações comerciais normais de um bem similar, destinado ao consumo interno no membro exportador. Para efeitos desse cálculo, as normas da OMC autorizam a exclusão, sob certas condições, das vendas no mercado interno do membro exportador que sejam inferiores ao custo de produção do bem comercializado. Nesses termos, essas transações comerciais podem não ser consideradas operações comerciais normais.

Quando as vendas do bem similar no mercado interno do membro exportador não existirem, ou ainda quando não for possível estabelecer uma comparação válida dessas vendas com os preços de exportação, seja em razão das particularidades do mercado interno do membro exportador, seja em virtude do diminuto volume dessas vendas nesse mercado, as normas da OMC permitem que outros critérios sejam utilizados para o cálculo do valor normal de referido bem. Tais critérios são as vendas do bem similar a um terceiro membro da OMC e o chamado valor normal construído. No primeiro caso, trata-se dos preços de exportação praticados no mercado de um terceiro membro da $\mathrm{OMC}$, sob a condição de que esses preços sejam representativos e praticados no curso de operações comerciais normais. Na segunda hipótese, o membro da OMC que efetua a investigação sobre a existência do dumping realiza o cálculo do custo de produção exportadoras (ÓRGÃO DE APELAÇÃO DA OMC, 2008, § 95). 
majorado, inclusive, de um montante razoável correspondente ao lucro - do bem objeto da investigação. ${ }^{16}$

É a partir desse cálculo do valor normal do bem - que será definido seguindo esses diferentes critérios - que se pode identificar o dumping no comércio internacional. A constatação de sua existência não é, todavia, suficiente para que o membro da OMC importador seja autorizado a tomar medidas contra essa conduta comercial. O membro importador deve, ainda, constatar, por meio de uma investigação objetiva e imparcial, a ocorrência de danos à indústria nacional e o nexo de causalidade entre esses danos e o dumping.

Uma vez feitas essas constatações, o membro da OMC importador tem o direito de impor os direitos antidumping sobre os bens importados em causa. A imposição de tais medidas, ressalta-se, é um direito conferido pelo direito da OMC aos seus membros, e não uma obrigação.

As normas da OMC determinam, em pormenores, o conteúdo dessas medidas, o momento em que elas podem ser impostas e a sua duração. O artigo VI, § 2 do Acordo Geral de 1994 preceitua: “com o fim de neutralizar ou impedir 'dumping' a Parte Contratante poderá cobrar sobre o produto, objeto de um 'dumping' um direito 'anti-dumping' que não exceda a margem de 'dumping' relativa a esse produto" (WORLD TRADE ORGANIZATION, 1994, tradução nossa). A margem de dumping, por sua vez, é justamente o quantum da diferença entre o preço em que o bem é introduzido no mercado do membro da OMC importador e o seu valor normal.

Os direitos antidumping constituem uma barreira comercial, porquanto elas significam um direito adicional imposto sobre o bem importado. As normas da OMC autorizam explicitamente essa imposição e mesmo a consolidação das tarifas aduaneiras não impede que ela seja levada a efeito. É o que dispõe, a propósito, o artigo II, § 2, a), do GATT de 1994 (WORLD TRADE ORGANIZATION, 1994).

As normas da OMC permitem que os seus membros imponham direitos antidumping provisórios, quando se constatam, a título preliminar, a presença do dumping e dos danos dele decorrentes à indústria nacional e se verifica a necessidade de evitar danos à indústria nacional durante o curso das investigações. Os direitos antidumping definitivos, por seu turno, somente devem ser impostos ao final de tais investigações.

Quanto à duração desses direitos, o artigo 11 do Acordo antidumping estabelece que eles deverão permanecer em vigor somente no tempo e na medida necessários para neutralizar o dumping que causa o dano aos produtores nacionais.

À luz das observações precedentes, conclui-se que as medidas antidumping autorizadas pelo direito da OMC têm por finalidade fazer desaparecer o efeito concorrencial da sobre a metodologia a ser adotada nesse cálculo. Ver, por exemplo, o art. $2^{\circ}$ do Acordo antidumping. 
prática do dumping. Os direitos antidumping provisórios e definitivos têm um efeito direto sobre os preços dos bens importados, o que impede que eles sejam comercializados a um preço inferior ao seu valor normal. Desse modo, a indústria nacional é favorecida, pois os direitos antidumping melhoram a sua posição concorrencial em relação aos bens importados.

De modo análogo à disciplina sobre os subsídios, o direito conferido aos membros da OMC de reagirem ao dumping tem um importante contrapeso: eles apenas podem fazêlo nos termos e condições previstos pelo direito da OMC.

O Órgão de Apelação ressaltou, em diferentes oportunidades, que as únicas medidas antidumping admitidas pelo direito da OMC são aquelas que estão nele previstas. Por esse motivo, a lei antidumping norte-americana de 1916, a qual estabelecia sanções penais e civis contra o dumping, foi considerada uma violação ao sistema multilateral de comércio (ÓRGÃO DE APELAÇÃO DA OMC, 2000, § 131-132). Foi com base nesse mesmo fundamento que a emenda Byrd - disposição da legislação norte-americana a qual previa a outorga dos recursos arrecadados pelos direitos antidumping aos produtores domésticos afetados por essa prática comercial - foi condenada pelo OSC (ÓRGÃO DE APELAÇÃO DA OMC, 2000, § 124).

A finalidade das normas da $\mathrm{OMC}$ em matéria de subsídios e dumping não é, portanto, apenas a de restringir essas práticas comerciais, mas também a de limitar as reações a essas práticas por parte dos membros por elas lesados (ÓRGÃO DE APELAÇÃO DA OMC, 2000, § 252). Há a clara preocupação em se evitar a multiplicação de medidas comerciais restritivas que utilizem o dumping e os subsídios como simples pretexto para a sua imposição.

De todo modo, resta claro que, segundo o direito da OMC, os membros dessa organização internacional têm o direito de reagir à prática dos subsídios e dumping. As medidas compensatórias e os direitos antidumping são permitidas e não constituem uma medida protecionista vedada pelo sistema multilateral de comércio. Assim, ao passo que diferentes restrições comerciais são proibidas pelas normas da $\mathrm{OMC},{ }^{17}$ as medidas de defesa comercial contra os subsídios e o dumping são autorizadas. Essa observação nos conduz a refletir sobre o porquê desse tratamento diferenciado a tais medidas.

\section{A lealdade DA CONCORRÊNCIA INTERNACIONAl E A Disciplina do DUMPING E DOS SUBSÍDIOS}

Em seu aludido discurso sobre o comércio leal, o presidente Reagan propugnou pelo nivelamento do campo em que se desenrola o jogo da concorrência no comércio internacional

17 Veja-se, por exemplo, a proibição da imposição de tarifas aduaneiras acima do valor das tarifas consolidadas (artigo II do GATT 1994) ou ainda a vedação de barreiras quantitativas ao comércio internacional (artigo XI do GATT 1994) (WORLD TRADE ORGANIZATION, 1994). 
- a instituição de um level playing field. Nessa concepção, os operadores do comércio internacional, que fazem concorrência entre si, deveriam desfrutar de condições equânimes para a produção e comercialização de seus bens e serviços.

É essa ideia de nivelamento da arena em que ocorre a disputa pelo comércio internacional que fundamenta as medidas de defesa comercial contra os subsídios e o dumping. Tal fundamentação sempre suscitou muitas resistências dos economistas da corte liberal, por impedir que os consumidores de bens importados usufruam dos benefícios do livre comércio (2.1). De todo modo, os subsídios e o dumping não esgotam o tema sobre a desigualdade das condições de concorrência no comércio internacional, o que levanta maiores indagações sobre a conveniência e a oportunidade da adoção de medidas comerciais contra o dumping e os subsídios (2.2).

\section{I AS MEDIDAS COMERCIAIS CONTRA OS SUBSÍDIOS E O DUMPING E O NIVELAMENTO DO CAMPO DA CONCORRÊNCIA INTERNACIONAL}

Segundo a sua própria definição trazida pelo Acordo SMC, o subsídio implica a concessão, pelo membro da OMC, de uma vantagem a uma empresa. E essa vantagem comercial pode ser decisiva na disputa pelo mercado internacional. Com efeito, por força do subsídio concedido pelo membro da OMC, a empresa beneficiada passa a ter uma posição particularmente privilegiada para obter ganhos de participação no mercado internacional.

Desse modo, a empresa estrangeira subsidiada aumenta as suas vendas às custas de empresas nacionais, não em razão de sua organização eficiente, da engenhosidade de seus proprietários ou de seus funcionários ou ainda da melhor qualidade de seus produtos. Em vez disso, tal acréscimo dá-se pelos subsídios que ela recebe de seu Estado.

As empresas nacionais do Estado importador apontam, assim, um grande desequilíbrio criado pelos subsídios: ao passo que elas contam apenas com as suas próprias forças para desenvolver as suas atividades, a empresa estrangeira é apoiada por contribuições financeiras outorgadas pelo seu Estado. Haveria, portanto, uma ausência de tratamento isonômico entre os atores do comércio internacional. Em síntese, a luta pela clientela seria, nesse caso, uma disputa muito desigual. Mais do que isso, as contribuições financeiras dos Estados concedidas às empresas poderiam se tornar o fator determinante da competitividade internacional, e não mais a eficiência da organização produtiva. Nessa perspectiva, seria líder no mercado internacional não a empresa mais eficiente, mas a que recebesse maiores subsídios.

Assim, há subjacente à disciplina dos subsídios no comércio internacional a finalidade de se assegurarem condições isonômicas de competição no mercado internacional. É muito significativa, a esse propósito, a autorização dada pelos Acordos da $\mathrm{OMC}$ à imposição de medidas compensatórias aos bens subsidiados. Tais medidas, como nós vimos, anulam os efeitos comerciais da concessão do subsídio, pois tornam os bens importados mais caros na exata razão do subsídio concedido. Dessa maneira, o equilíbrio das condições de concorrência é restabelecido. 
Essa mesma ordem de considerações pauta a disciplina do dumping no mercado internacional. Conforme salientado, o dumping consiste em uma prática de preços perpetrada por empresas no comércio internacional, as quais são, na maioria dos casos, pessoas jurídicas de direito privado. Em um primeiro momento, seria surpreendente enquadrar o dumping na disciplina das condutas desleais dos Estados no comércio internacional. Para que esse aspecto do dumping se torne mais claro, cabe fazer uma breve referência histórica sobre a legislação antidumping no direito comparado e internacional.

$\mathrm{Na}$ primeira metade do século XX, o dumping era, sobretudo, definido como uma prática de diferenciação de preços no mercado internacional: a exportação de um bem a um preço inferior ao praticado no mercado nacional do país exportador. ${ }^{18}$ Diferentes explicações são apresentadas para justificar essa prática de discriminação de preços, inter alia: estratégia para adquirir novos mercados e a necessidade de comercializar o excedente de produção em um contexto de recessão econômica ${ }^{19}$ e em setores em que existem ganhos de economia de escala. ${ }^{20}$

Todavia, para que essa conduta comercial possa ser posta em prática de modo durável e sistemático, a empresa em questão deve estar protegida da concorrência internacional no mercado nacional do Estado exportador. São, assim, as barreiras comerciais do Estado exportador, que protegem o seu mercado nacional, a causa do dumping: elas possibilitam que as empresas domésticas vendam no mercado nacional a um preço maior do que aquele

Veja-se, por exemplo, a definição de dumping dada por Jacob Viner em um conhecido relatório apresentado à Liga das Nações: "L'expression dumping, au sens que lui donnent les écrivains soucieux de précision, signifie la vente à l'exportation, à des prix plus bas que ceux qui sont faits, à la même époque et dans les mêmes circonstances, aux acheteurs sur le marché intérieur" (VINER, 1926, p. 2).

19 Essa motivação da prática do dumping está associada à própria origem desse termo da língua inglesa : “Le terme 'dumping' vient du verbe to dump qui signifie 'déblayer', 'jeter bas' et dont le sens argotique 'verser sur le carreau d'une mine le contenu du wagonnet' a donné par extension 'se débarrasser d'un stock de marchandises à tout prix'” (BOUDANT, 1991, p. 15). Jacob Viner assim discorre sobre a origem da palavra dumping: "It has long been customary to speak of one market as the 'dumping-ground' for the 'surplus' products of another market when the producers of the latter for any reason sold their commodities in the former at unusually low prices. From this usage it was a natural outcome to speak of selling in a distant market at cut prices as 'dumping', but the word used in this sense appears not to have entered into the literature of economics until the first years of the twentieth century" (VINER, 1991, p. 1).

20 Já na primeira metade do século $\mathrm{XX}$, a prática do dumping já era identificada em setores econômicos em que há grandes economias de escala e que demandam um grande investimento no capital fixo, a exemplo do setor siderúrgico. Joel Boudant menciona o exemplo da indústria siderúrgica alemã que vendia o seu aço à Inglaterra a um preço duas vezes menor que os preços praticados no mercado alemão. Atualmente, é corrente a imposição de direitos antidumping aos produtos da siderurgia. Sobre o assunto, ver Boudant (1991, p. 16). 
praticado em outros mercados. Sem essa proteção do Estado exportador, é muito difícil que as empresas adotem essa estratégia comercial. ${ }^{21}$ E é justamente essa proteção que propicia a essas empresas lucros monopolistas em suas vendas nos mercados domésticos, adquirindo, assim, a musculatura financeira necessária para conquistar mercados estrangeiros com preços módicos.

É sintomático que, no início do século XX, a prática de dumping fosse atribuída com frequência às empresas norte-americanas e alemães - dois Estados muito protecionistas àquela época. A propósito, a primeira lei nacional antidumping foi a canadense de 1904, a qual foi editada principalmente em resposta ao dumping da indústria norte-americana do aço. ${ }^{22}$ Nos dias atuais, a prática de dumping é com frequência atribuída às empresas que operam em Estados que adotam ou adotaram políticas protecionistas. ${ }^{\mathbf{2 3}}$

Por conseguinte, se uma empresa pode vender, de modo sistemático, bens no estrangeiro a um preço inferior ao praticado no mercado nacional, isso não se dá, muito provavelmente, em razão de sua maior produtividade. Essa diferenciação de preços resulta, em vez disso, de uma vantagem comercial propiciada por um Estado às suas empresas: a proteção do mercado nacional contra bens estrangeiros. Os concorrentes de outros Estados dessas empresas, por sua vez, não dispõem do mesmo benefício. Daí a associação entre o dumping e a desigualdade das condições de concorrência causadas por políticas públicas.

Sob essa óptica, o fundamento do combate ao dumping é muito similar ao dos subsídios, muito embora o dumping não vise diretamente uma ação estatal. No caso dos subsídios, a ação estatal que desequilibra o jogo da concorrência internacional é a contribuição financeira dada pelo Estado às empresas domésticas. Na hipótese do dumping, o foco é colocado

21 Sobre o assunto, ver notadamente a obra clássica de Jacob Viner (1926, p. 110-131) sobre o dumping.

22 Após essa adoção da lei canadense, outros Estados passaram a dispor de legislação antidumping, como os Estados Unidos, a Inglaterra, a França e o Japão. Por conseguinte, as legislações nacionais sobre esse tema são bem anteriores ao Acordo Geral sobre Tarifas e Comércio de 1947 (General Agreement on Tariffs and Trade - GATT 1947). Para um estudo comparativo sobre as legislações nacionais antidumping do começo do século XX, ver especialmente Trendelenburg (1926). Sobre o assunto, ver também Mény (1909, p. 72-73).

"In other words, dumped exports are the result of mercantilist politics of the exporting country. This is well illustrated when looking at the main 'targets' of the Community's anti-dumping action. In the 80s, many cases were initiated against imports from Japan. In the 90s, the focus shifted to imports from Korea and subsequently to India, while today the majority of cases is directed against imports from China. Each of these countries was either in the past and/or is still today pursuing an economic policy which tried to improve the competitiveness of its economic operators (often with a global strategy) inter alia by restricting import competition. Thus, dumping could be even considered as an integral part of these mercantilist strategies" (KHAN; SCHARF; MÜLLER, 2009, p. 7). 
sobre a proteção pelo Estado de seu mercado doméstico, a qual causa o mesmo desequilíbrio. De modo muito similar às medidas compensatórias que combatem os subsídios, os direitos antidumping apenas tornam sem efeito esse desequilíbrio, pois o seu montante não pode ser superior à margem de dumping.

As ações contra os subsídios e o dumping fundamentam-se, portanto, na manutenção da lealdade da concorrência internacional, aqui entendida como uma certa igualdade de condições de concorrência entre as empresas que disputam entre si o mesmo mercado.

Um outro motivo é, por vezes, colocado para respaldar o combate aos subsídios e ao dumping: o temor de que essas condutas comerciais signifiquem, no longo prazo, a formação de monopólios ou oligopólios internacionais. Nessa linha de argumentação, os bens importados subsidiados ou que forem vendidos a preços de dumping causariam o desaparecimento da concorrência e abririam o caminho para que as empresas estrangeiras adquirissem, no futuro, uma posição de monopólio ou de oligopólio no mercado internacional. Uma vez conquistada tal posição, essas empresas estrangeiras estariam livres para impor preços excessivos em suas vendas. Os benefícios de curto prazo decorrentes dessas condutas - a importação de bens mais baratos - seriam ilusórios, pois tais preços teriam um aumento muito substancial no futuro.

Sucede, contudo, que essa ameaça à própria existência da concorrência no mercado internacional supõe que seja possível, do ponto de vista econômico, obter essa posição de monopólio ou oligopólio em um horizonte de tempo maior. Ora, tal possibilidade é muito difícil de ser constatada no mercado internacional, haja vista a grande competição entre um número significativo de empresas de diferentes Estados em tal mercado. De todo modo, quando as medidas contra o dumping e subsídios são acionadas, essas considerações sobre a estrutura do mercado internacional não são ponderadas, o que indica que o combate aos monopólios ou oligopólios internacionais não constitui a finalidade dessas ações. ${ }^{24}$

Portanto, as ações de defesa comercial contra o dumping e os subsídios têm por fundamento o tratamento isonômico a ser reservado a empresas nacionais e estrangeiras, de sorte a impedir que condutas estatais quebrem esse tratamento e sejam determinantes na batalha pela clientela no âmbito internacional.

Essa fundamentação não é isenta de críticas. Os economistas partidários do livre comércio têm, de longa data, dirigido acerbas críticas às medidas contra o dumping e os subsídios. ${ }^{25} \mathrm{Na}$ linha de seu pensamento, a questão primordial são os benefícios trazidos aos

24 Os oligopólios no mercado internacional são circunscritos a determinados setores da atividade econômica, a exemplo da indústria aeronáutica. Sobre o assunto, ver: Bliss (1997, p. 313-328); Gifford e Matsuhita (1997, p. 369-331); Hindley (1997, p. 333-348).

25 Essas críticas à legislação antidumping datam de sua implementação no início do século XX: "Many free traders, especially in England during the sugar-bounty controversy and the general tariff controversies of more 
consumidores finais e à indústria que necessita de bens intermediários, em razão da importação de bens a preços menores. Sob esse ponto de vista, pouco importam as causas econômicas do menor preço dos bens importados.

É ilustrativa a fábula irônica criada por Frédéric Bastiat (2005, p. 89-93), em um conhecido discurso à câmara de deputados francesa no século XIX, sobre uma petição dos fabricantes de velas contra a concorrência desleal do sol. A isso se acresce a anedota dos economistas liberais sobre a melhor resposta a ser dada pelo Estado importador aos subsídios concedidos pelo Estado exportador: uma nota de agradecimento à embaixada desse último Estado. ${ }^{26}$ Nesse diapasão, as contribuições financeiras dos Estados exportadores aos seus bens constituem um subsídio ao consumo do Estado importador.

Em suma, para os economistas de corte liberal, as vantagens materiais advindas da importação de bens independem dos motivos pelos quais os preços desses bens são menos elevados.

A única hipótese em que os economistas partidários do livre comércio admitem o combate aos subsídios e ao dumping é aquela em que eles representam uma ameaça à própria

recent years, have taken the position that restrictions on the free importation of dumped commodities are as undesirable as import restrictions of the ordinary protectionist kind” (VINER, 1991, p. 144). Economistas partidários do livre comércio fazem críticas do mesmo jaez nos dias de hoje: "As an economic point of view, prohibiting price discrimination seldom makes a great deal of sense unless the price discrimination is predatory pricing in disguise. Forcing producers to sell for one price, either domestically or internationally, may lead to profit-maximizing firm to avoid servicing some markets entirely, and such a response may entail a net welfare loss. Further, alleged dumping, if it does not lead do predatory behaviour, provides consumers with inexpensive goods, and this result is typically welfare enhancing” (LEVINSOHN, 1997, p. 344). No mesmo sentido, César Mattos afirma: "Não obstante, preços diferentes entre vários mercados não implicam, obrigatoriamente, infração à concorrência. Em análises de defesa da concorrência, é sabido que estratégias de discriminação de preços entre mercados diferentes podem estar elevando e não reduzindo o bem-estar do conjunto dos consumidores nos vários mercados afetados. Isso implica ainda que a intervenção da autoridade, no sentido de evitar a discriminação de preços entre mercados quaisquer, seja dentro de um mesmo país ou não, pode resultar em redução e não aumento de bem-estar” (MATTOS, 1999, p. 274).

"Of particular relevance to the WTO/GATT legal system is the perspective of importing nations regarding subsidized imports. In general, nations benefit from a reduction in the prices of goods that they import. It is straightforward to demonstrate in the standard case of a competitive industry that the economic losses to import-competing domestic firms are outweighed by the gains to domestic consumers from the opportunity to purchase goods or services more cheaply. The intuition for this result draws on the fact that domestic firms hurt by lower prices can economize on their losses by shifting productive resources to activities with higher returns, while domestic consumers gain from not only the price reduction on all units purchased at the previously higher prices, but reap additional gains from the opportunity to purchase more units at a lower price. The net gain to an importing country from lower priced imports does not depend in any way on the reason why price declines - a price decline due to foreign subsidies has the same economic consequences in the standard case as an equivalent price decline due to other factors. This observation lies behind a well-known economist's quip to the effect that the proper response of an importing nation to subsidies that lower the price of imports is to 'send a thank-you note to the embassy'” (SYKES, 2005, p. 92, notas de rodapé omitidas). 
concorrência internacional. Contudo, conforme foi dito alhures, é relativamente raro que ela ocorra na prática, tendo em vista os obstáculos econômicos à formação de monopólios e oligopólios no plano internacional.

Essas críticas dos economistas liberais são especialmente dirigidas às medidas antidumping. As normas da OMC sobre o dumping são flexíveis a ponto de permitirem que os membros da OMC calculem o valor normal dos bens importados com suporte em outros parâmetros que não sejam as vendas internas do membro exportador. Ora, a diferença entre os preços cobrados no mercado interno e no mercado externo é o critério por excelência que põe em evidência o protecionismo do membro exportador que beneficia as suas empresas. Na medida em que esse critério não é adotado, o direito antidumping deixa de ser justificado por essas práticas protecionistas.

Nos EUA, as críticas às medidas antidumping impostas pelo governo norte-americano são muito frequentes por parte dos economistas liberais. ${ }^{27} \mathrm{Em}$ um influente e detalhado estudo sobre a política comercial norte-americana entre 1995 e 1998, Lindsey Brink (2014) demonstrou que somente duas das 107 investigações norte-americanas que identificaram a prática de dumping baseavam-se exclusivamente nos preços praticados no mercado interno do membro exportador. Ao afastar-se desse critério, as ações antidumping não podem ser justificadas com fulcro no argumento segundo o qual as empresas que praticam dumping estão protegidas em seus mercados nacionais. Cabe aqui ressaltar que as normas da OMC, conforme visto, autorizam o uso nas investigações sobre o dumping de outros critérios que não os preços vigentes no mercado interno do membro exportador. Além disso, segundo Brink, quando as autoridades norte-americanas utilizavam-se do valor normal construído para determinar o dumping, elas inflavam esse valor artificialmente, a exemplo do uso de margens de lucros muito elevadas. ${ }^{28}$ Daí a dicotomia identificada por Lindsey Brink entre a retórica e a realidade das ações antidumping norte-americanas: elas seriam impostas mesmo na ausência de uma conduta desleal por parte do membro exportador.

Em igual sentido, Vincent Aussilloux e Gilles Mourre criticam o excesso de medidas antidumping por parte das autoridades europeias. Analisando os dados entre 1994 e 1997,

27 Ver, por exemplo: Barfield (2003).

28 Conforme já assinalado, no caso do valor normal construído, são as próprias autoridades nacionais que investigam a prática de dumping que calculam tal valor, a partir dos custos de produção de tal bem, majorado de uma razoável margem de lucro. Outros membros da OMC, como a União Europeia, têm também adotado com frequência o recurso ao valor normal construído em suas investigações antidumping, o que tem também gerado uma série de questionamentos: "Calculation of constructed normal values involves a variety of calculation and allocation choices. In addition, the calculation of a 'reasonable' profit margin is a tricky business. Consequently, constructed normal values are unpredictable and arbitrary, compared to price-based normal values" (VERMULST, 2005, p. 108). 
os referidos autores afirmaram que 61 das 70 medidas antidumping foram adotadas sem que houvesse qualquer risco de monopolização do mercado por parte da empresa que pratica o dumping. Para os referidos autores, as ações antidumping europeias protegiam setores econômicos pouco produtivos e com vantagens comparativas declinantes, em prejuízo do consumidor (AUSSILLOUX; MOURRE, 2001, p. 19-53). ${ }^{29}$

Em síntese, as ações de defesa comercial são, muitas vezes, utilizadas com os mesmos objetivos e com os mesmos efeitos das barreiras comerciais clássicas: ${ }^{\mathbf{3 0}}$ a proteção de setores econômicos pouco competitivos em prejuízo dos consumidores e das empresas importadoras de insumos. Por conseguinte, as diferenças entre o protecionismo tradicional e as medidas de defesa comercial podem diluir-se. ${ }^{31}$

Assim, é inequívoco que as ações contra o dumping e subsídios são autorizadas pelo direito da OMC. Daí não decorre, no entanto, que tais ações sejam necessariamente benéficas, sobretudo em uma abordagem que salienta os benefícios trazidos pelo livre comércio. Ademais, a justificativa posta para essas ações - o tratamento isonômico entre concorrentes no mercado internacional - apresenta inúmeros problemas, conforme se verá adiante.

\subsection{O TRATAMENTO ISONÔMICO ENTRE CONCORRENTES NO MERCADO INTERNACIONAL E AS DIFERENTES FORMAS DE ATUAÇÃO DO ESTADO EM FAVOR DE SUAS EMPRESAS}

$\mathrm{Na}$ teoria clássica do comércio internacional, as vantagens comparativas dos Estados eram descritas, principalmente, com apoio nas diferenças climáticas e geográficas entre os países. Para retomar o célebre exemplo de David Ricardo (1977, p. 111-130), os produtores portugueses de vinho beneficiam-se das condições climáticas e geográficas propícias à vinicultura em Portugal. Tais condições colocam os vinicultores portugueses em uma situação muito vantajosa em relação aos vinicultores de outros países.

Nesse enfoque, a ênfase da explicação sobre os termos de trocas internacionais - o que cada país importa e exporta - recai sobre as características naturais de cada Estado. Essa abordagem clássica não foi totalmente abandonada. De fato, fatores naturais constituem uma parte importante dessa explicação. Por exemplo, os países que dispõem de uma grande extensão de terras cultiváveis são grandes exportadores agrícolas, ${ }^{\mathbf{3 2}}$ pois seus

29 Ver também Barbet (1995, p. 3-33).

30 Pode-se citar como exemplo de barreira comercial clássica ou tradicional a imposição de elevados direitos aduaneiros sobre os bens importados.

31 Conforme visto na introdução do artigo, os discursos dos presidentes Dilma Rousseff e Ronald Reagan aludem a uma diferença clara entre o protecionismo clássico e as medidas de defesa comercial.

32 Esse é notavelmente o caso do Brasil. Sobre o assunto, ver: The Miracle of the cerrado (THE ECONOMIST, 2014). 
produtores agrícolas têm uma vantagem comparativa - a ampla disponibilidade de um fator de produção indispensável para a produção agrícola - que outros produtores de outros países não possuem.

Todavia, essa ênfase nas características naturais dos Estados negligencia as vantagens comparativas dos países que são criadas por políticas públicas. O papel das políticas educacionais para o comércio internacional é uma ilustração disso. Um sistema público de ensino de alta qualidade traz muitas vantagens para as empresas nacionais que necessitam de mão de obra qualificada em seu processo de produção. Aliás, as políticas educacionais atuais estão cada vez mais focadas nesse objetivo: a formação do chamado "capital humano". ${ }^{33}$ Muitos dos países que mais exportam bens industrializados sofisticados são precisamente aqueles onde são localizadas universidades de excelência internacional. ${ }^{34}$

Outras políticas públicas que fomentam a competitividade das empresas nacionais são dignas de registro. As grandes obras públicas de infraestrutura de transportes, de telecomunicações e de energia reduzem os custos de produção das empresas e lhes propiciam um contexto econômico e social muito favorável ao desenvolvimento de suas atividades. ${ }^{35}$ Evidentemente, esses mesmos benefícios não são usufruídos por empresas situadas em Estados com infraestrutura deficiente.

É essa influência dos recursos naturais e das políticas governamentais sobre a competitividade das empresas que conduz ao questionamento sobre a pertinência da noção de nivelamento das condições de concorrência no mercado internacional. Conforme visto, certas diferenças das condições de concorrência dizem respeito a fatores naturais, como a geografia ${ }^{36}$ e o clima. No tocante às políticas públicas, há uma gama muito variada de ações

33 Para uma visão crítica sobre esse assunto, ver, especialmente, Laval (2003).

34 Veja-se, por exemplo, o caso do Vale do Silício - região dos Estados Unidos caracterizada pela alta concentração de universidades de ponta e de empresas de alta tecnologia.

"Effective modes of transport for goods, people, and services - such as quality roads, railroads, ports, and air transport - enable entrepreneurs to get their goods and services to market in a secure and timely manner, and facilitate the movement of workers to the most suitable jobs. Economies also depend on electricity supplies that are free of interruptions and shortages so that businesses and factories can work unimpeded. Finally, a solid and extensive telecommunications network allows for a rapid and free flow of information, which increases overall economic efficiency by helping to ensure that businesses can communicate, and that decisions made by economic actors take into account all available relevant information" (WORLD ECONOMIC FORUM, 2009, p. 5).

Para se restringir a apenas mais um exemplo, se um país é geograficamente próximo dos principais mercados consumidores mundiais, as empresas que estão localizadas nesse país terão custos de transportes bem menores para levar os seus produtos a tais mercados que as empresas que estão situadas em países distantes. Paul Krugman é um dos principais economistas a enfatizar o peso da geografia sobre o comércio internacional: "Instead, the analysis of international trade makes virtually no use of insights from economic or location theory. We normally model countries as dimensionless points within which factors of production 
governamentais que exercem tal influência. É difícil, assim, isolar uma ação estatal que possa ser caracterizada como subsídio e fonte de desequilíbrio das condições de competição no mercado internacional.

Esse é um dos principais pontos do Acordo SMC: especificar as formas de atuação do membro da $\mathrm{OMC}$ em prol da produção nacional que são consideradas subsídios. É muito revelador que o primeiro artigo do Acordo SMC tenha, justamente, por objeto a definição do subsídio. Conforme salientou o Órgão de Apelação da $\operatorname{OMC}(2004$, § 52), nem todas as medidas estatais que conferem vantagens às empresas nacionais são subsídios. Com efeito, conforme visto, é indispensável, para que ocorra tal caracterização, que a medida seja enquadrada como sendo uma contribuição financeira do membro da OMC, assim como a define o artigo $1^{\circ}$ do Acordo SMC.

Do mesmo modo, os direitos antidumping apenas podem ser impostos se a prática do dumping houver sido constatada, tal como ela é conceituada pelo direito da OMC. A importação de bens a preços módicos que não correspondam a tal definição não pode sofrer medidas antidumping, ainda que tais práticas resultem de políticas públicas do membro exportador que desequilibrem o jogo da concorrência internacional em favor de suas empresas.

Em diferentes ocasiões, o Órgão de Apelação censurou a imposição pelos membros de medidas compensatórias a políticas estatais benéficas às empresas nacionais que não se enquadravam no conceito de subsídio do direito da OMC. ${ }^{37}$ O Órgão, também, condenou as ações e investigações antidumping dos membros da OMC por não respeitarem os critérios definidos pelo direito da OMC para a determinação do dumping. ${ }^{\mathbf{3 8}}$

À luz das considerações acima feitas, resta claro que uma das finalidades principais do direito da OMC consiste justamente em restringir as ações de defesa comercial dos membros dessa organização internacional que se fundamentam na atribuição de condutas comerciais desleais dos seus pares na comunidade internacional. Na medida em que essas condutas comerciais desleais não se enquadrem na definição de dumping e de subsídios prevista no direito da OMC, medidas de defesa comercial não poderão ser adotadas pelos membros importadores.

can be instantly and costlessly moved from one activity to another, and even trade among countries is usually given a sort of spaceless representation in which transport costs are zero for all goods that can be traded" (KRUGMAN, 1991, p. 2). O caso do México é sempre citado como sendo um país particularmente favorecido pela sua proximidade geográfica com um grande país importador: os Estados Unidos. Ver, por exemplo: Questions relatives au travail et questions sociales dans les zones franches d'exportation (ORGANISATION INTERNATIONALE DU TRAVAIL, 1998).

37 Ver, por exemplo, Painel da OMC (2001, § 7.18-7.141) e Órgão de Apelação da OMC (1999b, § 84-124).

38 Ver, por exemplo, Órgão de Apelação da OMC (2001, § 53-55) e Órgão de Apelação da OMC (2009, $\S 242-317)$. 
É por esses motivos que acusações contra determinados Estados que praticariam dumping ambiental, social e monetário em benefício de suas empresas seriam dificilmente aceitas pelo OSC. Com efeito, as condutas dos Estados em matéria ambiental, trabalhista e cambial podem muito dificilmente ser enquadradas como subsídio ou dumping, o que impede os Estados de se utilizarem de medidas compensatórias ou de direitos antidumping nessas hipóteses.

Nos acordos comerciais preferenciais, quando a questão da articulação entre comércio e respeito à legislação trabalhista é disciplinada, ela não está inserida nas normas sobre o dumping. Nos acordos de livre-comércio celebrados pelos EUA, por exemplo, essa temática é tratada em um capítulo especial e o desrespeito às normas trabalhistas não é conceituado como dumping. É bem verdade que, nesses acordos, há a possibilidade de sanções comerciais serem impostas na eventualidade de esse desrespeito ocorrer. Mas tais sanções não são medidas antidumping. ${ }^{39}$ Em outros termos, mesmo quando o tema dos direitos trabalhistas é regulado por normas internacionais comerciais, ele não o é no capítulo sobre o dumping.

Assim, acusações de dumping ambiental, social e monetário pertencem mais ao registro do discurso político ${ }^{40}$ do que jurídico. Em realidade, o dumping é uma forma específica de concorrência desleal, prevista de longa data nas legislações nacionais e em tratados internacionais. As alusões ao dumping ambiental, social e monetário consistem em uma forma de sinédoque: toma-se uma palavra que designa um modo particular de concorrência desleal (o dumping) para designar toda e qualquer forma de concorrência que se considera desleal.

De todo modo, essas imprecisões terminológicas bem revelam que a noção de nivelamento das condições de concorrência no mercado internacional está sujeita a diferentes

39 O tratado precursor nessa seara foi o acordo de cooperação no domínio do trabalho, assinado em 1993 entre México, Canadá e Estados Unidos. Trata-se a um dos acordos complementares ao NAFTA (North American Free Trade Agreement). Uma das disposições mais significativas desse acordo é o seu artigo $3^{\circ}$. Ele estabelece a obrigação dos Estados partes de promover a observação de suas respectivas legislações trabalhistas e de sua aplicação eficaz. Nos termos desse acordo, um painel poderá examinar se um dos Estados partes omitiu-se de modo sistemático em assegurar a aplicação eficaz das normas sobre a saúde e segurança no trabalho, o trabalho infantil e o salário mínimo. Se tal Estado parte persistir nessa omissão, o painel imporá uma compensação monetária a ser paga por esse Estado. Ver também as disposições análogas dos acordos de livre-comércio assinados pelos Estados Unidos com Singapura, Chile e República dominicana. Sobre o assunto, ver Grynberg e Qalo (2006, p. 619-653).

40 Ver, por exemplo, o discurso do presidente francês Nicolas Sarkozy de 15 de junho de 2009, na Organização Internacional do Trabalho. Nessa ocasião, o presidente francês defendeu novas normas internacionais contra "o dumping social", o "dumping monetário" e o "dumping ambiental”. Ver "Discurso de Nicolas Sarkozy na cúpula da OIT sobre a crise mundial e o emprego de 15 de junho de 2009”, disponível no site: http://www.ilo.org/. 
leituras. A multiplicidade de ações governamentais que impactam sobre essas condições é de tal ordem que esse nivelamento é dificilmente alcançável.

\section{CONCLUSÃo}

Não há dúvidas de que o direito da OMC incorporou a noção da desigualdade das condições de concorrência entre empresas ao autorizar os membros a reagirem contra o dumping e os subsídios. Essa incorporação não foi feita, todavia, de modo irrestrito, pois não apenas o direito da OMC determina quais remédios jurídicos podem ser adotados contra tais práticas, como também fixa com clareza os conceitos de dumping e subsídios para evitar interpretações extensivas acerca das razões que poderiam motivar essas ações de defesa comercial.

$\mathrm{O}$ direito da OMC não obriga os membros a reagirem por instrumentos de defesa comercial contra o dumping e os subsídios, apenas os autoriza a fazê-los sob determinadas condições. Seria, aliás, muito difícil que essa autorização não fosse concedida pelos Acordos da OMC, já que esses instrumentos eram utilizados muito antes do próprio surgimento do sistema multilateral de comércio. A isso se acresce a grande resistência dos Estados em renunciar, por meio de acordos comerciais, ao seu direito de se proteger contra o dumping e os subsídios.

Essas normas da OMC sobre o dumping e os subsídios são muito criticadas por economistas liberais, porque elas permitem que os membros imponham barreiras comerciais prejudiciais aos compradores de bens importados.

Tais controvérsias em torno do dumping e dos subsídios têm tido um alcance comercial muito grande nos dias atuais. Nos últimos decênios, houve uma diminuição notável dos direitos aduaneiros impostos pelos Estados aos bens importados. Diante desse quadro, medidas compensatórias e direitos antidumping, por serem autorizadas pelo direito da OMC, podem servir como último escudo para a proteção da produção nacional. ${ }^{41}$

O Brasil tem acompanhado essa tendência, tendo em vista o expressivo aumento das ações de defesa comercial pelo país, especialmente contra o dumping. ${ }^{42}$ Em um certo sentido, conforme se disse, é natural que esse crescimento tenha ocorrido, já que o Brasil acompanhou,

41 Os economistas partidários do livre comércio designam as medidas de proteção comercial como "novo protecionismo”. Nessa ordem de ideias, o antigo protecionismo - os direitos aduaneiros - teria sido substituído pelo novo protecionismo - as ações contra o dumping e os subsídios no comércio internacional (BHAGWATI, 1989, p. 72).

42 A dissertação de mestrado em economia de Jurandir Gonçalves Ferreira (2014, p. 19-21) traz dados interessantes a respeito. Entre 1987 - ano em que o Brasil passou a dispor de uma legislação contra o dumping - e 1995, foram abertas 65 investigações antidumping. Esse número aumentou para 111 entre 1996 a 2004 e chegou a 221 entre 2005 a 2013. Em relação aos direitos antidumping aplicados, eles passaram 
a partir da abertura comercial dos anos noventa, a evolução acima referida da diminuição de direitos aduaneiros. ${ }^{43}$ Nesse mesmo contexto, o discurso sobre a necessidade da isonomia de tratamento entre empresas nacionais e estrangeiras disseminou-se tanto no governo, quanto nos meios empresariais.

Essas mudanças no comércio exterior brasileiro merecem uma reflexão maior sobre o seu impacto no conjunto da economia brasileira. A circunstância de as medidas de defesa comercial serem autorizadas pela OMC não deve servir de salvo-conduto para qualquer tipo de crítica à sua imposição pelo Brasil. Tais medidas estão centradas na proteção de empresas nacionais, ameaçadas pela concorrência de empresas estrangeiras. Elas negligenciam, assim, os interesses dos compradores de bens importados - sejam consumidores finais, sejam indústrias importadoras de insumos.

Não se quer aqui dizer, evidentemente, que o Brasil deva se privar do uso desses instrumentos de defesa comercial. Conforme já foi dito amiúde, nos dias atuais, a participação da indústria na economia nacional tem decrescido, o que coloca em risco o esforço nacional de décadas de dotar o Brasil de um parque industrial forte e diversificado. Não nos parece, assim, adequado descartar de plano tais instrumentos, os quais podem se revelar úteis para incentivar as atividades de determinadas indústrias em dificuldades conjunturais e que têm grande potencial de se tornarem mais competitivas no futuro.

Admitir, a princípio, o uso desse instrumento de defesa comercial não implica referendar toda e qualquer medida de defesa comercial, desde que autorizada pelo direito da OMC. Como qualquer restrição à comercialização de bens importados, as medidas de defesa comercial têm custos para atores relevantes da economia nacional. E a justificativa para tais custos deve ir além da afirmação de elas serem autorizadas pelo direito da OMC ou de que elas constituem respostas a práticas comerciais desleais.

Parece-nos, assim, perfeitamente pertinente questionar medidas de defesa comercial que almejam proteger setores da economia nacional altamente oligopolizados ou que não se esforçam para se modernizarem e competirem com os bens estrangeiros. Não nos parece tampouco incabível exigir das empresas protegidas planos de investimento para tornarem-se mais competitivas, para que a proteção contra a concorrência estrangeira seja desnecessária no futuro. Esse debate é indispensável no momento atual em que o governo brasileiro tem feito uma necessária revisão do uso de outras medidas que beneficiam determinadas empresas e que têm

de 24 (1987-1995) para 61 (1995-2003). No último período (2005-2013), 107 direitos antidumping foram aplicados pelo governo brasileiro. Nesse mesmo lapso temporal, o país foi o segundo membro da OMC que mais abriu investigações antidumping. Sobre o crescimento das investigações antidumping no Brasil.

43 Deveras, as elevadas tarifas aduaneiras anteriormente praticadas pelo Brasil tornavam desnecessárias ações contra o dumping e os subsídios, haja vista que já representavam um sério óbice à comercialização de bens estrangeiros. 
custos substanciais para o conjunto da sociedade, a exemplo das desonerações fiscais e de créditos públicos subsidiados que se destinam apenas a determinados grupos econômicos. ${ }^{44}$

O exame dos fundamentos éticos e econômicos da disciplina do direito da OMC sobre as práticas comerciais desleais dos Estados parece-nos corroborar, assim, um enfoque mais crítico sobre o uso crescente dos instrumentos de defesa comercial pelo Brasil.

\section{REFERÊNCIAS}

AUSSILLOUX, Vincent; GILLES, Mourre. Une révision souhaitable de la procédure antidumping à l'OMC. Revue française d'économie, v. 15, n. 4, 2001.

BARBET, Philippe. Du dumping comme pratique loyale et de l'anti-dumping comme barrière aux échanges. Revue française d'économie, v. 10, n. 12, p. 3-33, 1995.

BARFIELD, Claude. High-tech protectionism: the irrationality of antidumping laws. Washington: AEI Press, 2003.

BASTIAT, Frédéric. Sophismes économiques. Paris: Société d'édition Les Belles Lettres, 2005.

BHAGWATI, Jagdish. Protectionism. Cambridge: The MIT Press, 1989.

The demands to reduce domestic diversity among trading nations. In: BHAGWATI, Jagdish N.; HUDEC, Robert E. (Org.). Fair Trade and Harmonization. Prerequisites for Free Trade? Economic Analysis. Cambridge: The MIT Press, 1997, p. 9-40.

BLISS, Cristopher. Trade and competition control. In: BHAGWATI, Jagdish; HUDEC, Robert E. Fair trade and harmonization: prerequisites for free trade? Volume I: Economic Analysis. Cambridge: The MIT Press, Cambridge, 1997, pp. 313-328.

44 Mais uma vez, não se trata de descartar de plano essas medidas. Trata-se, isto sim, de expor publicamente e de modo claro os seus custos, de cobrar das empresas beneficiadas contrapartidas e de avaliar com cuidado os seus benefícios e as suas desvantagens para o conjunto da economia brasileira no curto e longo prazo. 
BLYDE, Juan; MOREIRA, Maurício Mesquita; VOLPE, Christian. Desobstruindo artérias: o impacto dos custos de transporte sobre o comércio exterior da América Latina e Caribe. Washington: Banco Interamericano de Desenvolvimento, 2008.

BOUDANT, Joël. L'anti-dumping communautaire. Paris: Economica, 1991.

CRONTIRAS, Jean-Philippe; RUIZ FABRI, Hélène. L'OMC et les services publics. Paris: Institut du développement durable et des relations internationales, 2003.

FERREIRA, Jurandir Gonçalves. As ações antidumping no Brasil e seus efeitos nas importações. Dissertação de mestrado apresentada na Faculdade de Economia, Administração e Contabilidade da Universidade de Brasília, 2014.

GIFFORD, Daniel J.; MATSUHITA, Mitsuo. Antitrust or Competition Laws Viewed in a Trading context: harmony or dissonance. In: BHAGWATI, Jagdish; HUDEC, Robert E. Fair Trade and harmonization: prerequisites for free trade? Volume 2: Legal Analysis. Cambridge: The MIT Press, 1997, p. 369-331.

GRYNBERG, Roman; QALO, Veniana. Labour standards in US and EU preferential trading arrangements. Journal of World Trade, v. 40, p. 619-653, 2006.

HINDLEY, Brian. Competition law and the WTO: alternative structures for agreement. In: BHAGWATI, Jagdish; HUDEC, Robert E. Fair trade and harmonization: prerequisites for free trade? Volume 2: Legal Analysis. Cambridge: The MIT Press, 1997, p. 333-348.

KHAN, Nicholas; SCHARF, Tibor; MÜLLER, Wolfgang. EC and WTO anti-dumping law. Oxford: Oxford University Press, 2009.

KRUGMAN, Paul. Geography and trade. Cambridge: The MIT Press, 1991.

LAVAL, Christian. L'école n'est pas une entreprise. Le néo-libéralisme à l'assaut de l'enseignement public. Paris: Éditions La Découverte, 2003.

LESAFFRE, Hubert. Le mécanisme de règlement des différends au sein de l'OMC et le droit de la responsabilité internationale. Paris: L.G.D.J., 2007.

LEVINSOHN, James. Competition policy and international trade. In: BHAGWATI, Jagdish; HUDEC, Robert E. Fair trade and harmonization: prerequisites for free trade? Volume 1: Economic Analysis. Cambridge: The MIT Press, 1997. 
LINDSEY, Brink. The US Antidumping Law: Rhetoric versus Reality. The Cato Institute. Trade Policy Analysis, n. 7. 1999. Disponível em: <http://www.cato.org/publications/trade-policy-analysis/usantidumping-law-rhetoric-versus-reality>. Acesso em: 19 dez. 2014.

MATTOS, César. Harmonização das políticas de defesa da concorrência e comercial. Estudos Econômicos, São Paulo, v. 29, n. 2, p. 267-291, abr.-jun. 1999.

MÉNY, Marc. Le dumping. Tese de doutorado. Universidade de Paris, 26 de abril de 1909.

MERMILLOD, Louis. Essai sur la notion de concurrence déloyale en France et aux États-Unis. Paris: LGDJ, 1954.

NORTON, Patricia V. The effect of Article 10 bis of the Paris Convention on American unfair competition law. Fordham Law Review, v. 68, issue 1, p. 225-255, 1999.

ORGANISATION INTERNATIONALE DUTRAVAIL. Questions relatives au travail et questions sociales dans les zones franches d'exportation. Genève: Bureau international du Travail, 1998.

ORGÃO DE APELAÇÃO DA OMC. Canada - measures affecting the export of civilian aircraft. Relatório de 2 de agosto de 1999, WT/DS70/AB/R. 1999a.

Canada - measures affecting the importation of milk and the exportation of dairy products. Relatório de 13 de outubro de 1999,WT/DS103/AB/R. 1999 b.

United States - anti-dumping act of 1916. Relatório de 28 de agosto de 2000, WT/DS136/ AB/R, WT/DS162/AB/R. 2000.

European Communities - anti-dumping duties on imports of cotton-type bed linen from India. Relatório de $1^{\circ}$ de março de 2001, WT/DS141/AB/R. 2001.

United States - continued dumping and subsidy offset act of 2000. Relatório de 16 de janeiro de 2003, WT/DS217/AB/R, WT/DS234/AB/R. 2003.

. United States - final countervailing duty determination with respect to certain softwood from Canada. Relatório do Órgão de Apelação de 19 de janeiro de 2004, WT / DS257/ AB/R. 2004. . United States - subsidies on upland cotton. Relatório de 3 de março de 2005, WT /DS267/ AB/R. 2005. 
United States - final anti-dumping measures on stainless steel from Mexico. Relatório do Órgão de Apelação de 30 de abril de 2008, AB-2008-1, WT/DS344/AB/R. 2008.

. United States - continued existence and application of zeroing methodology. Relatório de 4 de fevereiro de 2009, WT/DS350/AB/R. 2009.

Canada - measures relating to the freed-in trade in tariff program. Relatório do Órgão de Apelação, 6 de maio de 2013, WT/DS426. 2013.

PAINEL DA OMC. United States - measures treating export restraints as subsidies. Relatório do Painel de 29 de junho de 2001, WT/DS194/R. 2001.

United States - subsidies on upland cotton. Relatório de 8 de setembro de 2004, WT/ DS267/R. 2004.

PIROVANO, Antoine. La concurrence déloyale en droit français. Revue internationale de droit comparé, v. 26, n. 3, p. 467-504, jul.-set. 1974.

RICARDO, David. Des principes de l'économie politique et de l'impôt. Paris: Flammarion, 1977.

SULLIVAN, Helena D. Regional jet trade wars: politics and compliance in WTO dispute resolution. Minnesota Journal of Global Trade, v. 12, p. 245-300, 2003.

SYKES, Alan O. Subsidies and countervailing measures. In: MACRORY, Patrick F. J.; APPLETON, Arthur E.; PLUMMER, Michael G. The World Trade Organization: legal, economic and political analysis. New York, 2005.

THE ECONOMIST. The miracle of the cerrado. 2010. Disponível em: <www.economist.com/ node/16886442>. Acesso em: 16 dez. 2014.

TINOCO SOARES, José Carlos. A concorrência desleal na América Latina e em outros países ilícitos civis, ilícitos penais, abuso de direito e a concorrência desleal através da publicidade comparativa e da publicidade enganosa. Revista dos Tribunais, v. 643, p. 249-272, maio 1989.

TRENDELENBURG, Ernst. Mémoire sur la législation de divers etats concernant la protection contre le dumping, notamment le dumping des changes. Sociedade das Nações - seção econômica e financeira. Conferência econômica internacional, 1926.

VERMULST, Edwin. The 10 major problems with the anti-dumping instrument in the European 
Community. Journal of World Trade, v. 39, 2005.

VINER, Jacob. Dumping: a problem in international trade. New York: Augustus M. Kelley Publishers, 1991. Mémorandum sur le dumping. Mémorandum préparé pour le Comité préparatoire de la Conférence économique internationale. Genève, 1926.

WORLD ECONOMIC FORUM. The global competitiveness report 2009-2010. Geneva: Switzerland, 2009.

WORLD TRADE ORGAniZATION. General Agreement on Tariffs and Trade (GATT 1994). WTO: Genebra, 1994. Disponível em: <https://www.wto.org/english/res_e/booksp_e/analytic_index_e/ gatt1994_e.htm>.Acesso em: 7 jun. 2017.

Daniel Damásio Borges

DOUTOR EM DIREITO PELA UNIVERSIDADE PARIS I (PANTHÉONSORBONNE) E PROFESSOR ASSISTENTE DOUTOR DE DIREITO InTERnaCIONAL dA FACULdAdE DE CIENCIAS Humanas E SOCIAIS DA Universidade Estadual PaUlista (UNESP), campus de Franca.

dadblauol.com.br 